INTERNATIONAL JOURNAL OF

MULTIDISCIPLINARY STUDIES IN ARCHITECTURE

AND CULTURAL HERITAGE

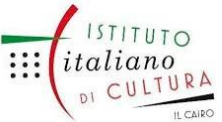

\title{
Using FTIR to Study the Chemical Degradation of Archaeological Wood in EL-
}

\section{Moez Street}

Alaa S. Emam a, Mohamed G. Shouman a, Mourad F. Mohamed a, *

a Conservation Department, Faculty of Archaeology, Cairo University

\begin{abstract}
Despite the complex structure of wood, it is a very sensitive material easy to degrade for several factors. FTIR spectroscopy is an excellent analytical method to characterize wood degradation by revealing chemical changes in wood structure in terms of the oxidation or hydrolysis mechanisms in the basic components: cellulose, hemicellulose and lignin. This paper presents assessing the different degradation types of archaeological wood in Historic Cairo as well as suggests a proposal schema in order to treat degraded wood.

Keywords

Conservation

$X R D$

FTIR

SEM

Archaeological Wood

Degradation
\end{abstract}

Introduction

Wood deterioration is faster in warm and humid condition than cool or dry places. The continuously submerged wood in water, microorganisms may attack, as well as wood kept constantly dry don't deteriorate signifactively since the subsequent deterioration process is very slow owing to limit air presence [1].

Fourier transform infrared spectroscopy (FTIR) have been widely used for determining the intera- and inter-hydrogen bonds in organic materials [2]. FTIR is an effective qualitative and quantitative analysis of wood through probing functional groups abundance and other specific structural features. It depends on molecular bond vibrations induced by IR radiation. Wood components: cellulose, hemi-cellulose and lignin have characteristic absorption Spectra in FTIR analysis, which show their functional groups in absorption area (1800-800) [3]. In absorption area (3300-3400) show wide $(\mathrm{OH})$ stretching (st) featured for cellulose [4] but (CH)st show in absorption area (2800-3000) [5]. (C=O) sh specified for 
hemicellulose show in absorption area (1735-1740) [6] [7]and absorption area (1090-1605) featured for lignin [8] [9].Absorption area of $(\mathrm{H}-\mathrm{O}-\mathrm{H})$ sh of cellulose show in (1640) [10] [11], but (C-O-C) sh show in (1165-1150) [12].FTIR-ATR ${ }^{1}$ enabled characterizing archaeological woods. FTIR data matrices showed the higher content of polysaccharides in beam wood, unless the shipwreck wood contained more lignin [13]. The comparison of 3 new hardwood species, birch, popular and lime, beside 15 samples taken from art objects was carried out via FTIR [14]. FTIR spectroscopy aided in assessing the photodegradation of wood. It was used for estimating the carbonyl band increase and the decrease of lignin vibrations of beech wood after sunlight and UV², with a mercury lamp, irradiation. In addition, there was dehydration as a result of ether splitting and hydroxyl $(\mathrm{OH})$ group consumption [15]. It was effective to monitor the degradation of different amorphous components of weathered wood. Its results confirmed the reduction of lignin and hemicellulose components of weathered wood agreeing with the resultsobtained via $\mathrm{XRD}^{3}$. The results referred to the significance of amorphous cellulose componentdegradation for wood exposure to the artificial weathering conditions [16]. FTIR is able to classify wood genotypes, species and origin according to the chemical composition of differentcell walls. FTIR is also an excellent analytical method to predict the chemical and biological processes of wood degradation that enables understanding wood chemistry and morphology. FTIR studied also the effect of interference between iron rust and microbiological damage on chemical and nature properties [17]. It was used for identifying the fungi composition living within wood and their effect on the chemical structure of wood as well as define the mechanismof wood fungal degradation [18]. It also focused on the role of free $(\mathrm{OH})$ radicals, as a one- electron oxidant, in $\alpha$-carbonyls for white-rot fungi on hard- and softwoods. These radicals caused lignin degradation by brown-rot fungi owing to cleaving methoxyl and aryl ether structure in order to form oxidized structure [19]. Beside, FTIR spectra was used of wood samples from Mohamed Ali's palace showing the effect of gesso layer on lignin, which causedlignin to be broken down severely [20]. The effects of salts on wood composition can be observed by FTIR. The content of lignin in archaeological wood decreased due to $\mathrm{NaCl}$ salt. By experiment, Calcium sulphate had a bad effect on cellulose more than 
INTERNATIONAL JOURNAL OF

MULTIDISCIPLINARY STUDIES IN ARCHITECTURE

AND CULTURAL HERITAGE

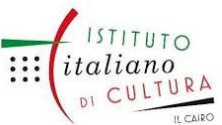

other salts like Natronsalt or $\mathrm{NaCl}$, although all salt affected badly on lignin or hemicellulose [21]

FTIR facilities selecting appropriate materials in wood restoration or conservation after the characterization of wood degradation [22]. It has the capacity of evaluating numerous treatments of wood by identifying the chemical components formed for the reactions and structural changes occurring inside wood [23]. It confirmed the higher resistance of scots pinewood treated with EEP 4 and organosilanes mixture to Coniophora puteana fungi [24]. It also proved the effectiveness of oxalic acid $1 \%$ to treat wooden samples stained iron rust, andits effect on. As noticed from comparing between standard sample and treated samples, there weren't any difference in functional groups of wood components after treatment [25]. In addition, it highlighted the bad effect of consolidation process by immersion on the wood maincomponents [26]. FTIR imagming ${ }^{5}$ is a perfect advanced analytical technique achieving a spatial resolution of the chemical composition. Therefore, it could be applied in order to studythe biological and biotechnological changes in cell wall of wood [27]. In this study, the basic goal was to identify the types of wood degradation at El-Moez Street in Historic Cairo, and suggest treatment plane.

1: Attenuated total reflectance, 2: Ultraviolet, 3: X-ray diffraction, 4: Ethanolic extract of propolis, 5: FTIR technique provided with microscopy.

\section{Materials and methods:}

1.1. Description of samples:

\begin{tabular}{l|ll}
\hline $\mathbf{1}$ & Saqyaat Bayt El-Kady Street & The window frame of building no. 8 \\
\hline $\mathbf{2}$ & $\begin{array}{l}\text { Saqyaat Bayt El-Kady Street } \\
\text { Sl-Nasser Mohamed Ibn Qalaoon's }\end{array}$ & The door street \\
\hline $\mathbf{3}$ & $\begin{array}{l}\text { The wooden wall side of Qibla Iwan } \\
\text { School Mohamed Ibn Qalawun's }\end{array}$ & $\begin{array}{l}\text { A door on the side of the Western } \\
\text { Iwan next to Qibla Iwan }\end{array}$ \\
\hline $\mathbf{4}$ & $\begin{array}{l}\text { El-Nasser Mohamed Ibn Qalawun's } \\
\text { School }\end{array}$ & An external window frame \\
\hline $\mathbf{5}$ & Ali El-Mutahar's Kutab and Sabil & The window frame \\
\hline
\end{tabular}




\section{\begin{tabular}{l|l}
7 & Sultan Qalawun's Mosque and School the bay wall door of shrine inside
\end{tabular}}

- Wood samples had different degradation forms.
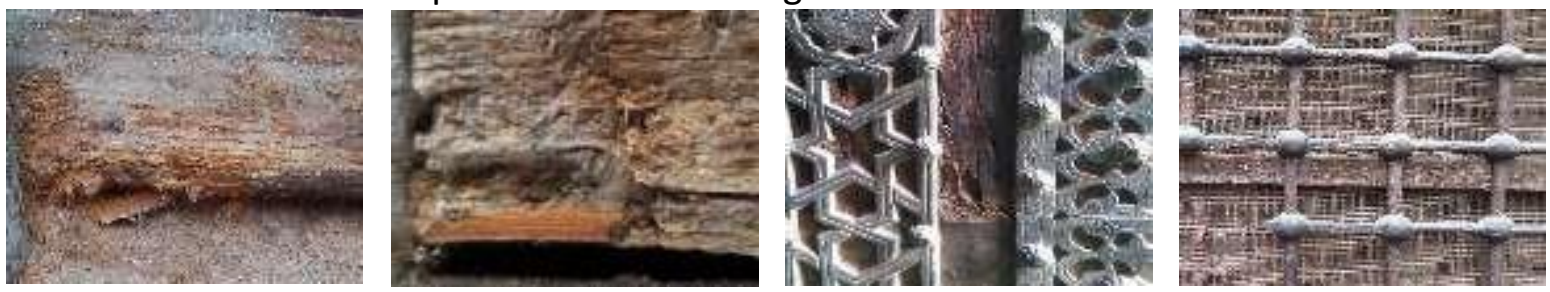

Examples of sampling sites and elements

1.2. Microscopic inspection:

In order to assess the different forms of wood degradation, the samples were examined via a Digital USB microscope 1000X, 5X Digital Zoom before FTIR analysis.

\subsection{FTIR spectroscopy:}

- Wood samples were sorted and divided according to the manifestation of deterioration.

- The samples were prepared by the $\mathrm{KBr}$ pellet technique. FTIR analysis was conducted on aNicolet $380 \mathrm{FT}$-IR Spectrometer to understand the reasons and mechanisms of degradationhappened to wood.

- An analysis of IR was conducted to study the effects and the extent of chemical changes deterioration and compare them with standard samples. 
INTERNATIONAL JOURNAL OF

MULTIDISCIPLINARY STUDIES IN ARCHITECTURE

\section{AND CULTURAL HERITAGE}

\section{Results and discussion:}

2.1. Results:

3. - The samples were examined and analyzed to show more accurate deterioration and location:
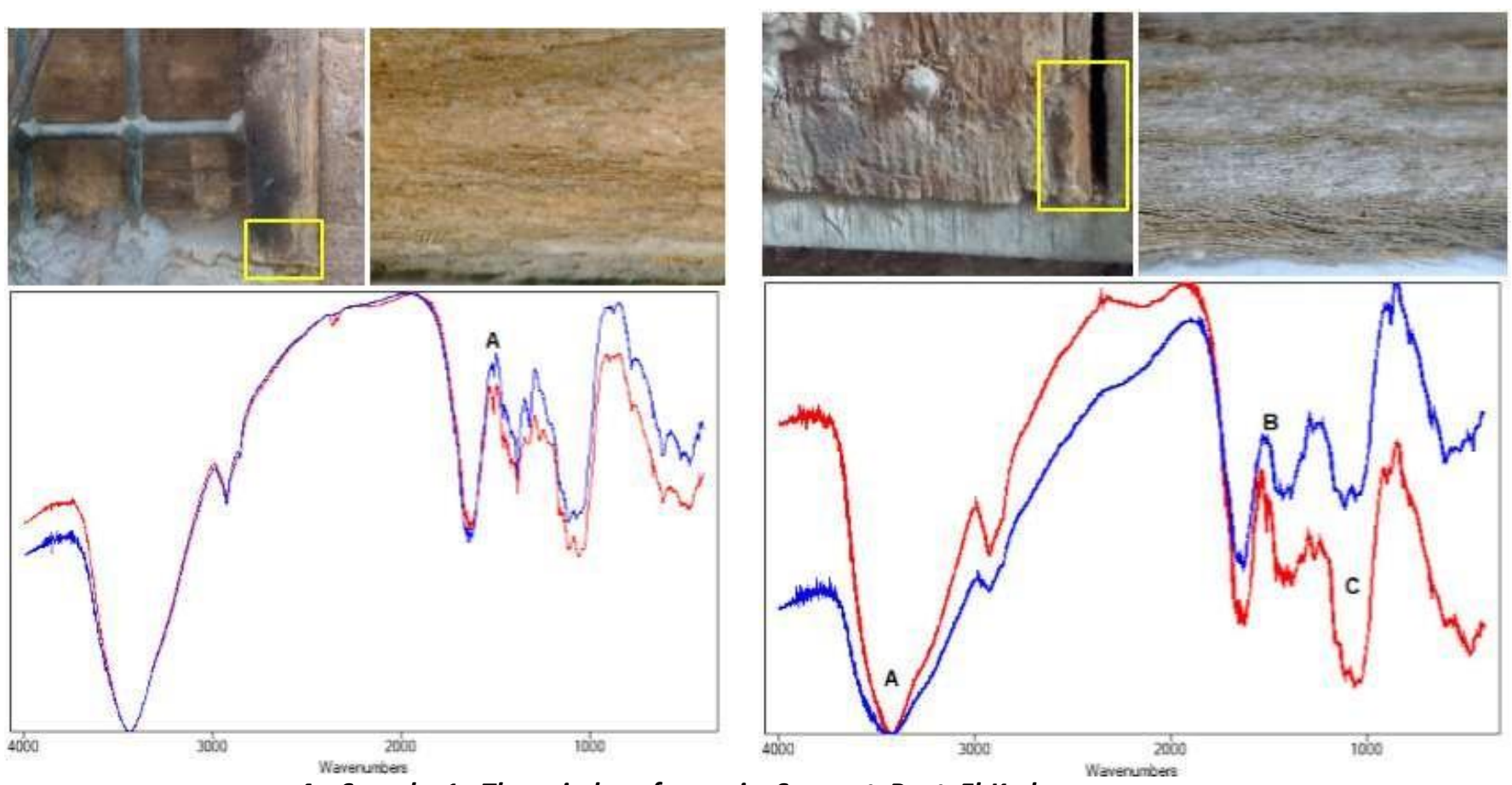

4. Sample 1: The window frame in Saqyaat Bayt El-Kady 
INTERNATIONAL JOURNAL OF

MULTIDISCIPLINARY STUDIES IN ARCHITECTURE

\section{AND CULTURAL HERITAGE}

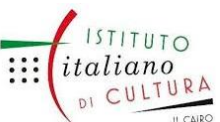

ISSN: $2735-4415$

VOLUME 3, ISSUE 2, 2020, 81-94.

www.egyptfuture.org/ojs/

Street

\begin{tabular}{|l|l|l|l|}
\hline Region & $\begin{array}{l}\text { W.n } \\
\left(\mathrm{Cm}^{-1}\right)\end{array}$ & $\begin{array}{l}\text { Function } \\
\text { group }\end{array}$ & Assignment \\
\hline A & 3430 & $\begin{array}{l}\text { OH } \\
\text { Stretching }\end{array}$ & Cellulose \\
\hline B & 1508 & $\begin{array}{l}\text { C=C } \\
\text { Stretching }\end{array}$ & Lignin \\
\hline C & 1068 & $\begin{array}{l}\text { C-O-C } \\
\text { Stretching }\end{array}$ & The cellulose DP \\
\hline
\end{tabular}

Sample 2: The door of Saqyaat Bayt El-

\begin{tabular}{|l|l|l|l|}
\hline Region & $\begin{array}{r}\text { W. } \boldsymbol{n} \\
\left(\mathrm{Cm}^{-1}\right)\end{array}$ & $\begin{array}{l}\text { Function } \\
\text { group }\end{array}$ & Assignment \\
\hline A & 3430 & $\begin{array}{l}\text { OH } \\
\text { Stretching }\end{array}$ & Cellulose \\
\hline B & 1511 & $\begin{array}{l}\text { C=C } \\
\text { Stretching }\end{array}$ & Lignin \\
\hline C & 1065 & $\begin{array}{l}\text { C-O-C } \\
\text { Stretching }\end{array}$ & $\begin{array}{l}\text { The cellulose } \\
\text { DP }\end{array}$ \\
\hline
\end{tabular}

Kady Street
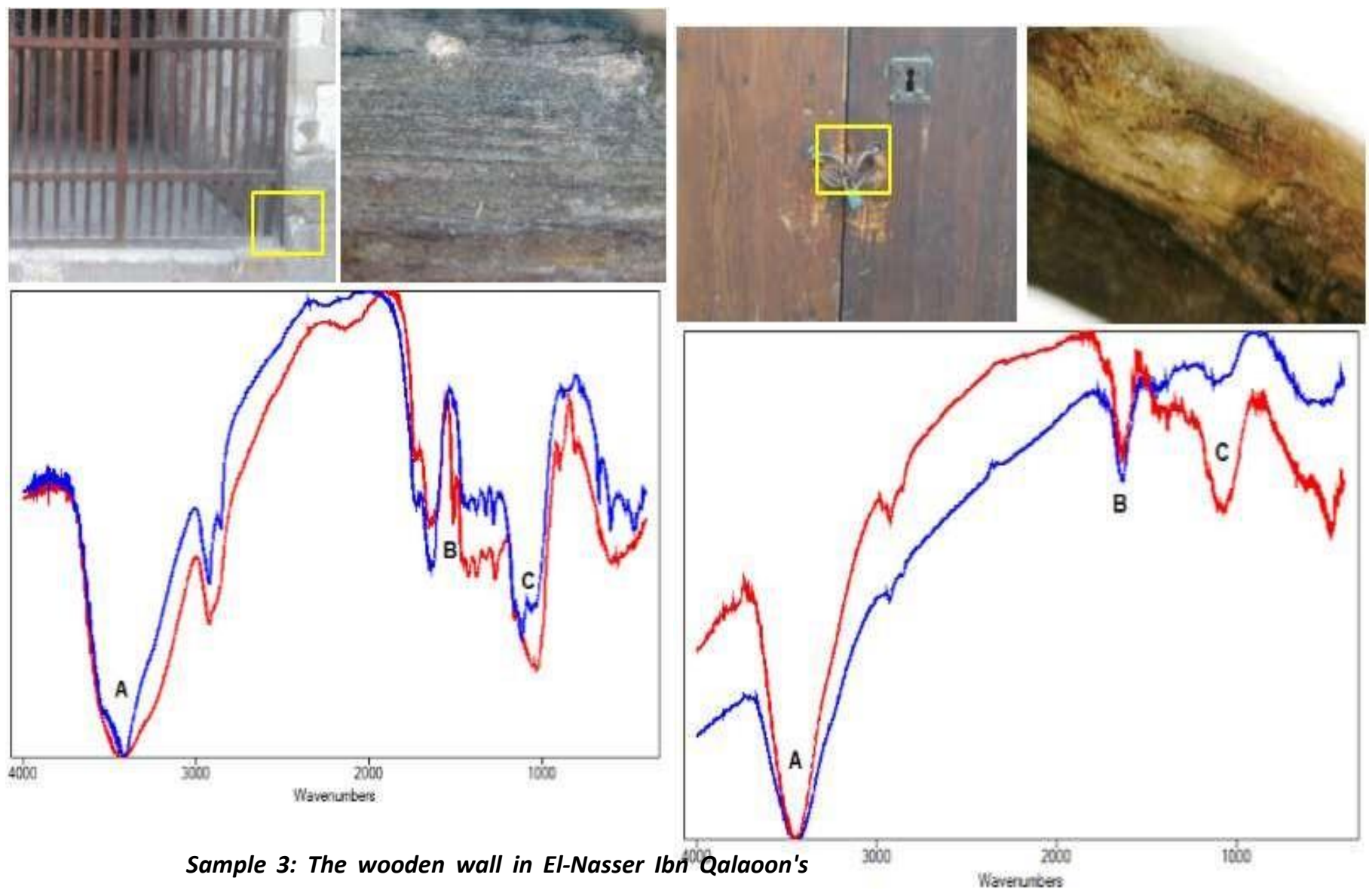

Sample 3: The wooden wall in El-Nasser Ibn Qalaoon's

Wavenunbers 
INTERNATIONAL JOURNAL OF

MULTIDISCIPLINARY STUDIES IN ARCHITECTURE

AND CULTURAL HERITAGE

ISSN: 2735-4415

VOLUME 3, ISSUE 2, 2020, 81-94.

www.egyptfuture.org/ojs/

School

\begin{tabular}{|c|c|c|c|}
\hline Region & $\begin{array}{l}\text { W.n } \\
\left(C m^{-1}\right)\end{array}$ & $\begin{array}{l}\text { Function } \\
\text { group }\end{array}$ & Assignment \\
\hline $\boldsymbol{A}$ & 3410 & $\begin{array}{l}\text { OH } \\
\text { Stretchin } \\
g\end{array}$ & Cellulose \\
\hline $\boldsymbol{B}$ & 1514 & $\begin{array}{l}\text { C=C } \\
\text { Stretchin } \\
g\end{array}$ & Lignin \\
\hline$C$ & 1065 & $\begin{array}{l}\text { C-O-C } \\
\text { Stretchin } \\
g\end{array}$ & $\begin{array}{l}\text { The cellulose } \\
\text { degree of } \\
\text { polymerization } \\
{[D P]}\end{array}$ \\
\hline
\end{tabular}

Ibn Qalaoon's School

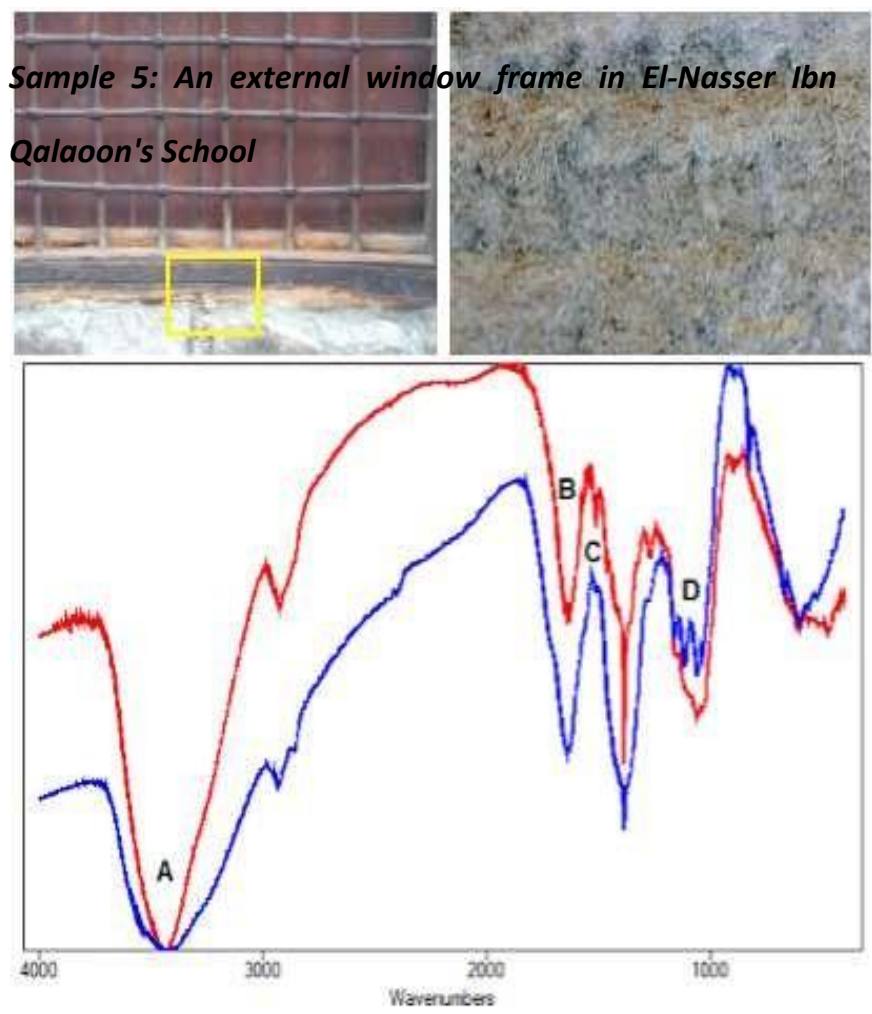

Sample 4: A western door in El-Nasser

\begin{tabular}{|c|c|c|c|}
\hline Region & $\begin{array}{l}\text { W.n } \\
\left(C m^{-1}\right)\end{array}$ & $\begin{array}{l}\text { Function } \\
\text { group }\end{array}$ & Assignment \\
\hline $\boldsymbol{A}$ & 3430 & $\begin{array}{l}\text { OH } \\
\text { Stretching }\end{array}$ & Cellulose \\
\hline $\boldsymbol{B}$ & 1654 & $\begin{array}{l}C=O \\
\text { Stretching }\end{array}$ & $\begin{array}{l}\text { Oxidation of } \\
\text { Cellulose }\end{array}$ \\
\hline$C$ & 1065 & $\begin{array}{l}C-O-C \\
\text { Stretching }\end{array}$ & $\begin{array}{l}\text { The cellulose } \\
\text { degree of } \\
\text { polymerization } \\
{[D P]}\end{array}$ \\
\hline
\end{tabular}

Sample 6: The window frame in Ali

El-Mutahar's Kutab andSabil

\begin{tabular}{|l|l|l|l|}
\hline Region & $\begin{array}{l}\text { W.n } \\
\left(\mathrm{Cm}^{-1}\right)\end{array}$ & $\begin{array}{l}\text { Function } \\
\text { group }\end{array}$ & \multicolumn{1}{|l|}{ Assignment } \\
\hline$A$ & 3439 & $\begin{array}{l}\text { OH } \\
\text { Stretching }\end{array}$ & Cellulose \\
\hline B & 1644 & $\begin{array}{l}\text { C=O } \\
\text { Stretching }\end{array}$ & $\begin{array}{l}\text { Oxidation of } \\
\text { Cellulose }\end{array}$ \\
\hline C & 1514 & $\begin{array}{l}\text { C=C } \\
\text { Stretching }\end{array}$ & Lignin \\
\hline D & 1062 & $\begin{array}{l}\text { C-O-C } \\
\text { Stretching }\end{array}$ & $\begin{array}{l}\text { The cellulose } \\
\text { DP }\end{array}$ \\
\hline
\end{tabular}


INTERNATIONAL JOURNAL OF

MULTIDISCIPLINARY STUDIES IN ARCHITECTURE

AND CULTURAL HERITAGE

\begin{tabular}{|l|l|l|l|}
\hline \multicolumn{2}{|c|}{$\begin{array}{l}\text { W.n } \\
\left(\mathrm{Cm}^{-1}\right)\end{array}$} & $\begin{array}{l}\text { Function } \\
\text { group }\end{array}$ & Assignment \\
Region & $\mathbf{3 4 4 0}$ & $\begin{array}{l}\text { OH } \\
\text { Stretching }\end{array}$ & Cellulose \\
\hline A & 1634 & $\begin{array}{l}\text { C=O } \\
\text { Stretching }\end{array}$ & $\begin{array}{l}\text { Oxidation of } \\
\text { Cellulose }\end{array}$ \\
\hline B & 1512 & $\begin{array}{l}\text { C=C } \\
\text { Stretching }\end{array}$ & Lignin \\
\hline C & 1062 & $\begin{array}{l}\text { C-O-C } \\
\text { Stretching }\end{array}$ & $\begin{array}{l}\text { The cellulose } \\
\text { DP }\end{array}$ \\
\hline D & & & \\
\hline
\end{tabular}
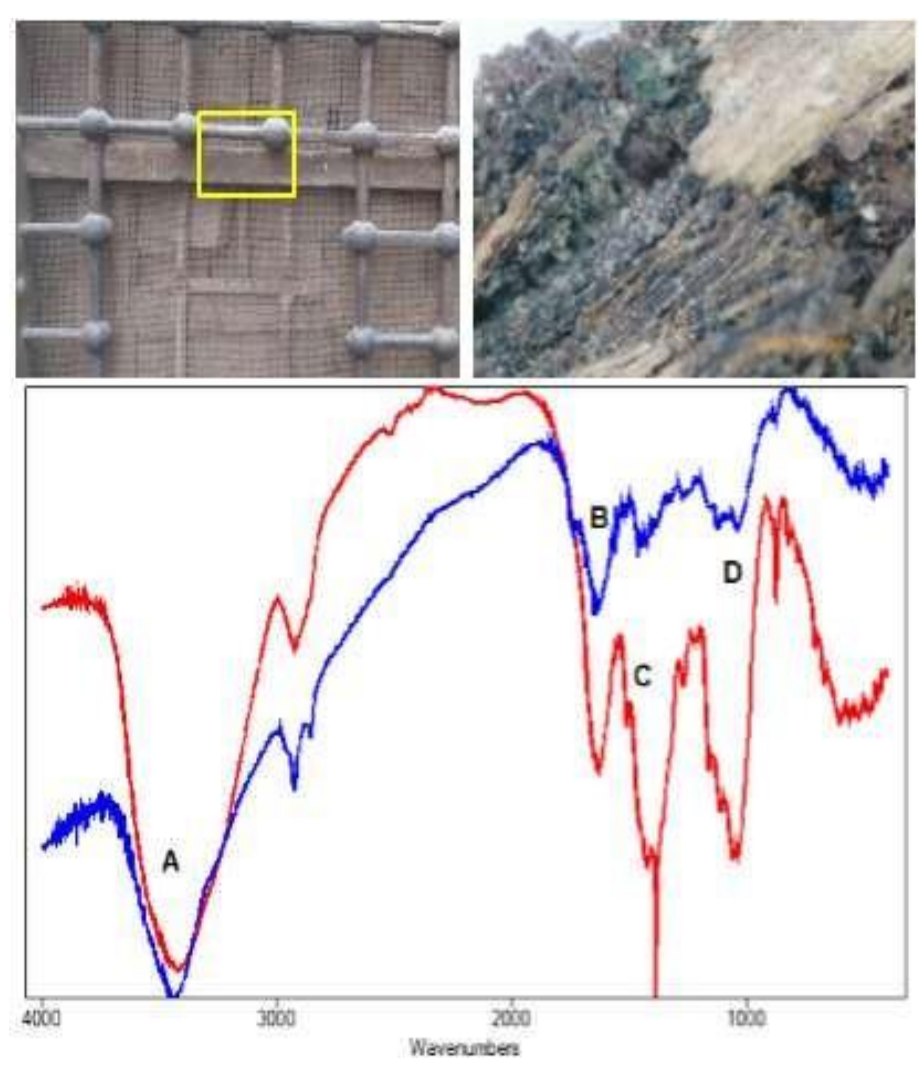


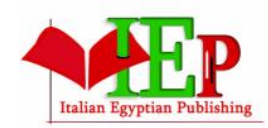

ISSN: 2735-4415

\section{INTERNATIONAL JOURNAL OF \\ MULTIDISCIPLINARY STUDIES IN ARCHITECTURE AND CULTURAL HERITAGE}

VOLUME 3, ISSUE 2, 2020, 81-94.

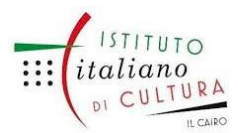

www.egyptfuture.org/ojs/
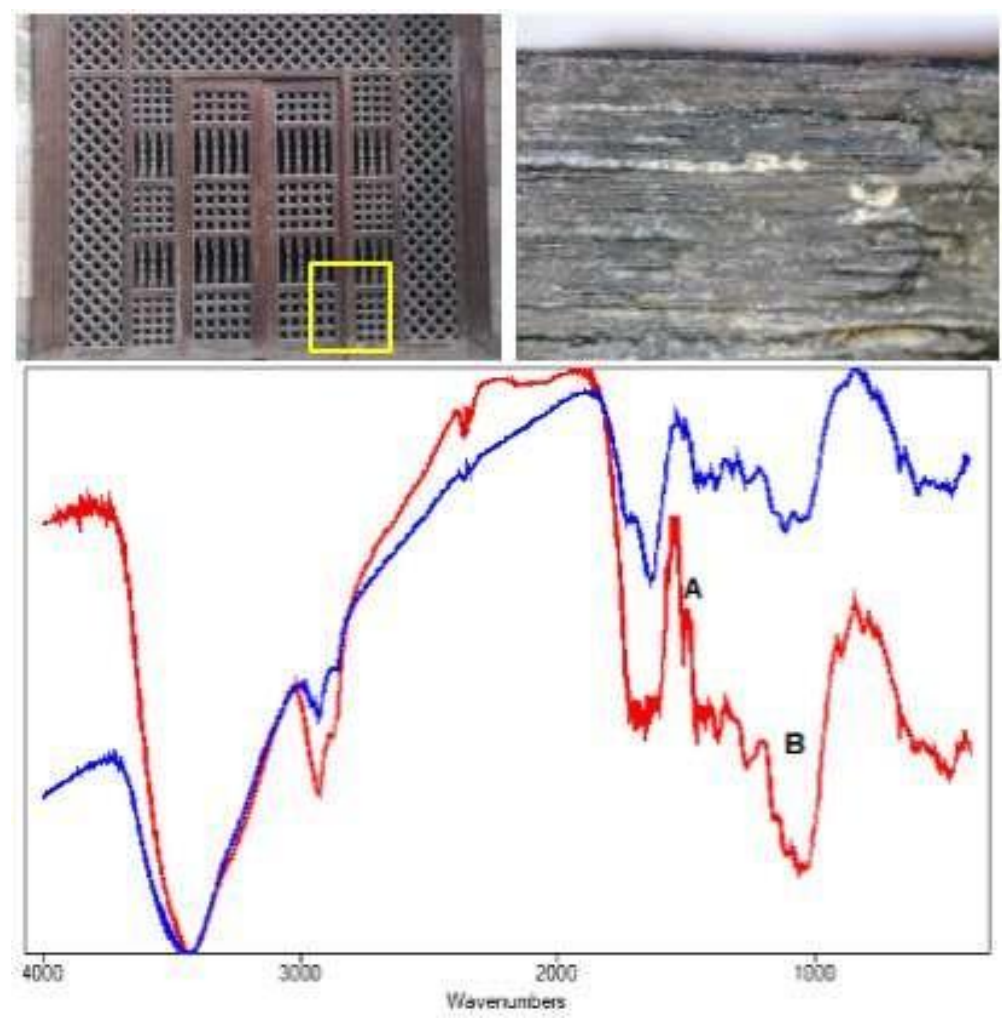

Sample7: the bay wall door of shrine inside Sultan Qalawun's Mosque and School

\begin{tabular}{|c|c|c|c|}
\hline Region & $\begin{array}{l}\text { Wave number } \\
\left(\mathrm{Cm}^{-1}\right)\end{array}$ & Function group & Assignment \\
\hline $\boldsymbol{A}$ & 1512 & $\begin{array}{l}C=C \\
\text { Stretching }\end{array}$ & Lignin \\
\hline $\boldsymbol{B}$ & 1059 & $\begin{array}{l}C-O-C \\
\text { Stretching }\end{array}$ & $\begin{array}{l}\text { The cellulose } \\
\text { DP }\end{array}$ \\
\hline
\end{tabular}

3. 2. Discussion: 
INTERNATIONAL JOURNAL OF

MULTIDISCIPLINARY STUDIES IN ARCHITECTURE

AND CULTURAL HERITAGE

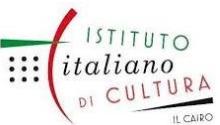

-there are results, which include Microscopic examination and FTIR analysis (red spectrums: unexploded samples "reference samples"), (blue spectrums: exposed samples "deteriorated samples").

1. Sample 1: Microscopic Examination: There weren't any antic thing to confirms the effect of Humidity, so we 'll used FTIR . FTIR analysis: Region(A) C=C st (lignin) $1512 \mathrm{~cm}^{-1}$ : there were slight changes in all compounds but the week influence of sodium chloride $(\mathrm{NaCl})$ on lignin can be observed throw low intensity of $\mathrm{C}=\mathrm{C}$ st at $1512 \mathrm{~cm}^{-1}$.

2. Sample 2: Microscopic examination: There are some splits and and crystals salt between wood fibers. FTIR analysis: R.A: $\mathbf{O H}$ st (cellulose) $3430 \mathrm{~cm}^{1}$, R.B: C=C st $1511 \mathrm{~cm}-1$, R.C: C-O-C st (polymerization degree of cellulose) $1065 \mathrm{~cm}^{-1}$ : there was

high acidity and hydrolysis made losing the lignin. Addition to high decrease in cellulose D.P.

3. Sample 3: Microscopic examination: There are some parts of calcium carbonatebetween wood fibers. FTIR analysis: R.A (OH st: $\left.3410 \mathrm{~cm}^{-1}\right), \boldsymbol{R} \cdot B\left(C=C\right.$ st $\left.1514 \mathrm{~cm}^{-1}\right), R \cdot C\left(C-O-C\right.$ st $\left.1065 \mathrm{~cm}^{-1}\right)$ : there was high drying and decreasing in cellulose D.P, as the effect of the sun which had shown in the weakness $(\mathrm{OH}$ st). There was high losingin lignin, result of $(\mathrm{NaCl})$ effect.

4. Sample 4: Microscopic examination: Dryness and high darky of external parts. FTIR analysis: R.A (OH st: $\left.3430 \mathrm{~cm}^{-1}\right), \boldsymbol{R} \cdot \boldsymbol{B}(\boldsymbol{C}=\mathbf{O}$ st $\left.1654 \mathrm{~cm}^{-1}\right), R . C\left(C-O-C\right.$ st $\left.1065 \mathrm{~cm}^{-1}\right)$ :resulting of acidity, there was slight widening in ( $\mathrm{OH} \mathrm{st})$. There was oxidation and decrease in cellulose D.P, as differences of humidity \&temperature.

5. Sample 5: Microscopic examination: Apperance of crystals salt between wood fibers. FTIR analysis: R.A (OH st: $\left.3439 \mathrm{~cm}^{1}\right)$, R.B $\left(C=O\right.$ st $\left.1644 \mathrm{~cm}^{-1}\right), R . C\left(C=C\right.$ st $\left.1514 \mathrm{~cm}^{-1}\right), R . D(C-O-C$ st 1062 $\mathrm{cm}^{1}$ ): there wasn't high band of lignin, as a result of acidity and solid. Slight increasing in oxidation, duet to decrease in cellulose D.P. 
INTERNATIONAL JOURNAL OF

MULTIDISCIPLINARY STUDIES IN ARCHITECTURE

AND CULTURAL HERITAGE

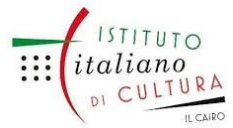

6. Sample 6: Microscopic examination: In external parts, there is combustion and fully. Decomposed. FTIR analysis: R.A (OH st: $\left.3440 \mathrm{~cm}^{-1}\right), R \cdot B\left(C=O\right.$ st $\left.1634 \mathrm{~cm}^{-1}\right), R \cdot C\left(C=C\right.$ st $\left.1514 \mathrm{~cm}^{-1}\right), R . D(C-$ O-C st $1062 \mathrm{~cm}^{-1}$ ): there was high acidity observed by the mechanisms of hydrolysis, shown in width and increasing band of $(\mathrm{OH} \mathrm{st})$, and oxidation shown slightly of $(\mathrm{C}=\mathrm{O} \mathrm{st})$.there was observable decrease in lignin content shown at $1514 \mathrm{~cm}^{-1}$ and cellulose D.P at $1062 \mathrm{~cm}^{-1}$.

7. Sample 7: Microscopic examination: There are effects of iron rust and darkness in some places. FTIR analysis: R.A (C=C st: $1512 \mathrm{~cm}$ $\left.{ }^{1}\right), \boldsymbol{R} \cdot \boldsymbol{B}\left(\boldsymbol{C}-\boldsymbol{O}-\boldsymbol{C}\right.$ st $\left.1059 \mathrm{~cm}^{1}\right)$ : therewas high decrease in cellulose D.P and full disappearance of lignin.

\section{Conclusion:}

Moreover previous, all wooden objects suffer from:

1- Lignin degradation due to the effect of salts especially $\mathrm{Na} . \mathrm{Cl}$ produced as a result ofwashing water containing chlorine or lime stone.

2- The decrease of cellulose polymerization for humidity and temperature changes causinghydrolysis and salts too.

3- High acidity owing to oxidation mechanisms because of drying and light exposure.

\section{References:}

[1] Wyckhuyse and Maldague, "Part I: Wood Pole Inspection by Infrared Thermography," in A Studyof Wood Insepection by Infrared

Thermography, New York, Springer, 2001, pp. 1-2.

[2] M. Fan, D. Dai and B. Huang, "Fourier Trasnform Infrared Spectroscopy for Natural Fibres," in

Fourier Transform - Materials Analysis, Shanghai - China, InTech, 2012, pp. 45-

68. 
INTERNATIONAL JOURNAL OF

MULTIDISCIPLINARY STUDIES IN ARCHITECTURE

AND CULTURAL HERITAGE

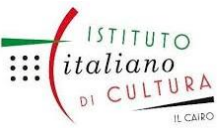

[3] e. a. Jiangtao Shi, FTIR Studies of the changes in Wood Chemistry from Wood Forming Tissueunder Inclined Tretment, 2012.

[4] C. T. R. Bodirlau, "Fourier Transform Infrared Spectroscopy and Thermal Analysis ofLignocellulose Fillers Treated with Organic Anhydrites," 2007.

[5] K. Kavkler, Application of FTIR and Raman Spectroscopy to Qualitative Analysis of StructuralChanges in cellulosic Fibres, tekstilec, 2012.

[6] A. e. a. Temiz, Effect of Accelerated Weathering on Surface Chemistry of Modified Wood, 2007.

[7] R. e. a. Ray, Wood Chemistry and Density: An Analog for Response to the Change of Carbon Sequestration in Mangroves, 2012.

[8] G. e. a. Bonifazi, Modeling color and Chemical Changes on Normal and Red Heart Beech Wood by Reflectance Spectrophotometry, fourier Transform Infrared Spectroscopy and Hyperspectrallmaging, 2015.

[9] E. e. a. Anderson, Infrared Studies of Wood Weathering, 1991.

[10] E. K. T. a. S. Gvsev, An Inferared Spectroscopic Investigation of the Hydration of cellulose, 1980.

[11] M. a. Picollo, Special Characterization of Ancient Wooden Artefacts with the use of Traditional IR Techniques and Art Device:A Methodologyical Approach, 2011.

[12] M. ,. e. a. Li, Structural Characterization of Steam-Heat Treated Tectona Grandis Wood Analyzed by FT-IR and 2D-IR Correlation Spectroscopy, 2015.

[13] M. Traore, J. Kaal and A. M. Cortizas, "Application of FTIR Spectroscopy to the Characterization of Archaeological Wood," Elsevier, vol. 153, no. 13861425, pp. 63-70, 2015.

[14] G. Matthaes, P. Matthaes, M. C. Buoso, M. De Poli and D. Zafiropoulos, "Discrimination of Different Wood Species of Artistic Interest Using Fourier Transform Infrared Spectroscopy," Italy.

[15] L. Tolvaj, "Monitoring of photodegradation for wood by infrared spectroscopy," Institute of Physics, University of West Hungary, Hungary.

[16] F. Lionetto, R. Del Sole, D. Cannoletta, G. Vasapollo and A. Maffezzoli, "Monitoring Wood Degradation during Weathering by Cellulose Cristallinity," Materials, vol. 5, no. 1996 - 1944, pp.1910 - 1922, 2012.

[17] W. A. E.-B. Abd El-Samad, An Experimental study to evaluate the effect of microbiogical on archaeological wood with the application of the new 
INTERNATIONAL JOURNAL OF

MULTIDISCIPLINARY STUDIES IN ARCHITECTURE

AND CULTURAL HERITAGE

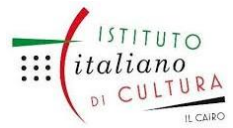

technique of treatment and conservation on chosen weapons, Cairo: Cairo University - Faculty of Archaeology, 2016.

[18] A. Naumann, U. Kues, S. Peddireddi and A. Polle, "Fourier Transform Infrared Microscopy in Wood Analysis," in FTIR Microscopy, Gottingen, Georg-August University, 2007, pp. 179-196.

[19] K. Fackler and M. Schwanninger, "How spectroscopy and microspectroscopy of degraded wood contribute to understand fungal wood decay," Springer, Vienna - Austria, 2012.

[20] M. F. M. Safa Abdelkader Mohamed Hamed, "Characterization of Archaeological Wood Stainedwith bat Excretions Using Various Analytical Techniques," 2016.

[21] O. M. M. Yonis, A study on the Effect of salts on composition of Antique wood and methods of treatment and conservation Applicated on chosen objects, Cairo: Cairo University - Faculty of Archaeology, 2016.

[22] Y. Zidan, N. El Hadidi and M. F. Mohamed, "Examination and Analyses od a Wooden Face at theMuseum Storage at the Faculty of Archaeology, Cairo University," Mediterraneam Archaeologyand Archaeometry, vol. 16, pp. 1-11, 2016.

[23] R. Bodirlau and C. A. Teaca, Fourier Transform Infrared Spectroscopy and Thermal Analysis of Lignocellulose Fillers Treated With Organic Anhydrides, lasi: Institute of Macromolecular Chemistry, 2007.

[24] M. Wozniak, I. Ratajczak, K. Szentner, P. Kwasniewska and B. Mazela, "Propolis and Organosilanes in Wood Protection. Part I: FTIR Analysis and Biological Tests," Ann. WULS-SGGW,For. and Wood Technol., vol. 91, no. Forestry and Wood Technology, pp. 218-224, 2015.

[25] W. A. E.-B. Abd El-Samad, A study on the Effect of Iron Rust on Properties of Antique Wood with Application of Conservation and treatment on Chosen Objects, Cairo: Cairo University - Faculty of Archaeology, 2010.

[26] M. G. Shouman, A. S. Abd El Sabour, A. Magdy, M. M. Abd El Salam, M. A. Abd El Hafez, S. A. E.

K. Hamed and M. Fawzy, "An Experimental Study to Evaluate the Effect of Consolidation Processes by Immersion on the Wood Composition," in Archaeology and Heritage in a Changing World, Cairo, Under publishing.

[27] A. Naumann and A. Polle, "FTIR Imaging as a New Tool For Cell Wall Analysis of Wood," New Zealand Journal of Forestry Science, vol. 36, pp. 53-59, 2006. 


\section{INTERNATIONAL JOURNAL OF MULTIDISCIPLINARY STUDIES IN ARCHITECTURE AND CULTURAL HERITAGE}

ISSN: $2735-4415$

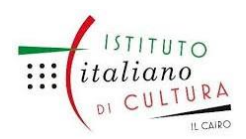

www.egyptfuture.org/ojs/

[28] R. Blanchette, Deterioration in historic and archaeological woods from terrestrial sites, art,biology and conservation, 2003.

Received: February 15, 2018

Accepted: April 20, 2018 